\title{
CRETACEOUS OCEANIC ANOXIC EVENTS IN WESTERN CONTINENTAL GREECE
}

Karakitsios V. ${ }^{1}$, Tsikos $\mathrm{H}^{2}$, Van Breugel Y. ${ }^{3}$, Bakopoulos I. ${ }^{1}$ and Koletti L. ${ }^{4}$

${ }^{1}$ Department of Geology, National University of Athens, Panepistimiopolis, 15784 Athens, Greece, vkarak@geol.uoa.gr

${ }^{2}$ Department of Geology \& Petroleum Geology, University of Aberdeen, King's College, Aberdeen AB24 3UE, Scotland, UK

${ }^{3}$ Royal Netherlands Institute of Sea Research (NIOZ), 1790 AB Den Burg, The Netherlands

${ }^{4}$ Museum of Natural History, Municipality of Amaroussion, P. Tsaldari 24-26, 15122 Amaroussion, Greece

\section{ABSTRACT}

Integrated chemostratigraphy and biostratigraphy in Cretaceous pelagic carbonate successions and associated organic sediments of the Ionian basin (western Greece) show the first documentation of the Cenomanian Turonian (OAE)2 and Lower Albian (OAE)1b Oceanic Anoxic Events from western Greece. Preliminary study of the Pindos basin (western Greece) has also identified a black shale horizon which may corresponds to the Lower Albian (OAE)1b Oceanic Anoxic Event.

\section{INTRODUCTION}

During the period from the Triassic to the Late Cretaceous, the external Hellenides (western Greece) constituted part of the southern Tethyan margin (Fig. 1), where siliceous and organic carbon-rich sediments were often associated facies.

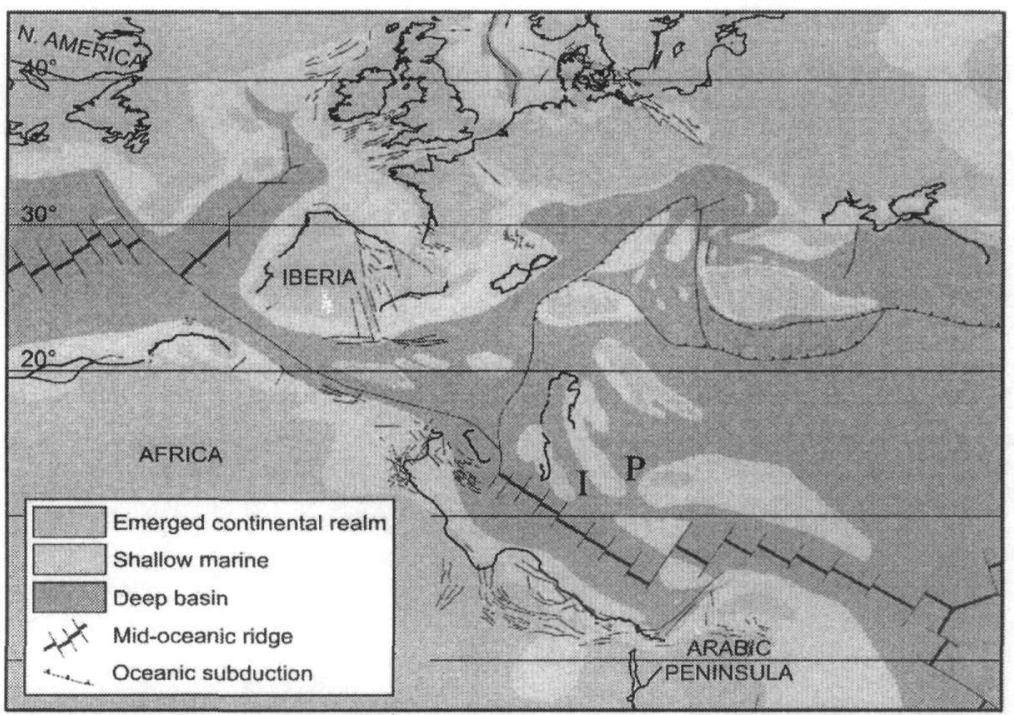

Figure 1. Aptian-Cenomanian Paleogeography of western Tethys and Central Atlantic (based on Dercourt et al. 1993): I: Ionian zone, P: Pindos zone. 
The Ionian and Pindos zones of western Greece (Fig.2) expose such basinal, thrust-imbricated sediments that document continental margin (Ionian zone) and continental-ocean margin basinal sequences (Pindos zone). Within these sequences, organic carbon-rich strata commonly develop, and some have been variously linked to the worldwide Oceanic Anoxic Events (Jenkyns, 1988; Karakitsios, 1995; Rigat is and Karakitsios, 1988; Danelian et al., 2002; Karakitsios et al. 2002; Tsikos et al., 2003; Karakitsios, 2003). The global stratigraphic occurrences of Cretaceous blackshales indicate that there are three major time envelops of black-shale deposition: late Barremian through Albian, late Cenomanian through early Turonian and Coniacian through Santonian (Jenkyns, 1999). These periods were particularly favorable for petroleum source-rock formation (more than half of the present petroleum reserves appear to have been generated during these periods). To explain the formation of OAEs, various controversy models have been proposed. They rely on changes either in sea-surface productivity (e.g. Wilson and Norris 2001) or preservation conditions (e.g. Erbacher et al. 2001).

In this paper, we present up to date results of our ongoing studies on integrated chemostratigraphy and biostratigraphy of Cretaceous pelagic carbonate successions and associated organic sediments of the Ionian basin (with some preliminary data of the Pindos basin).

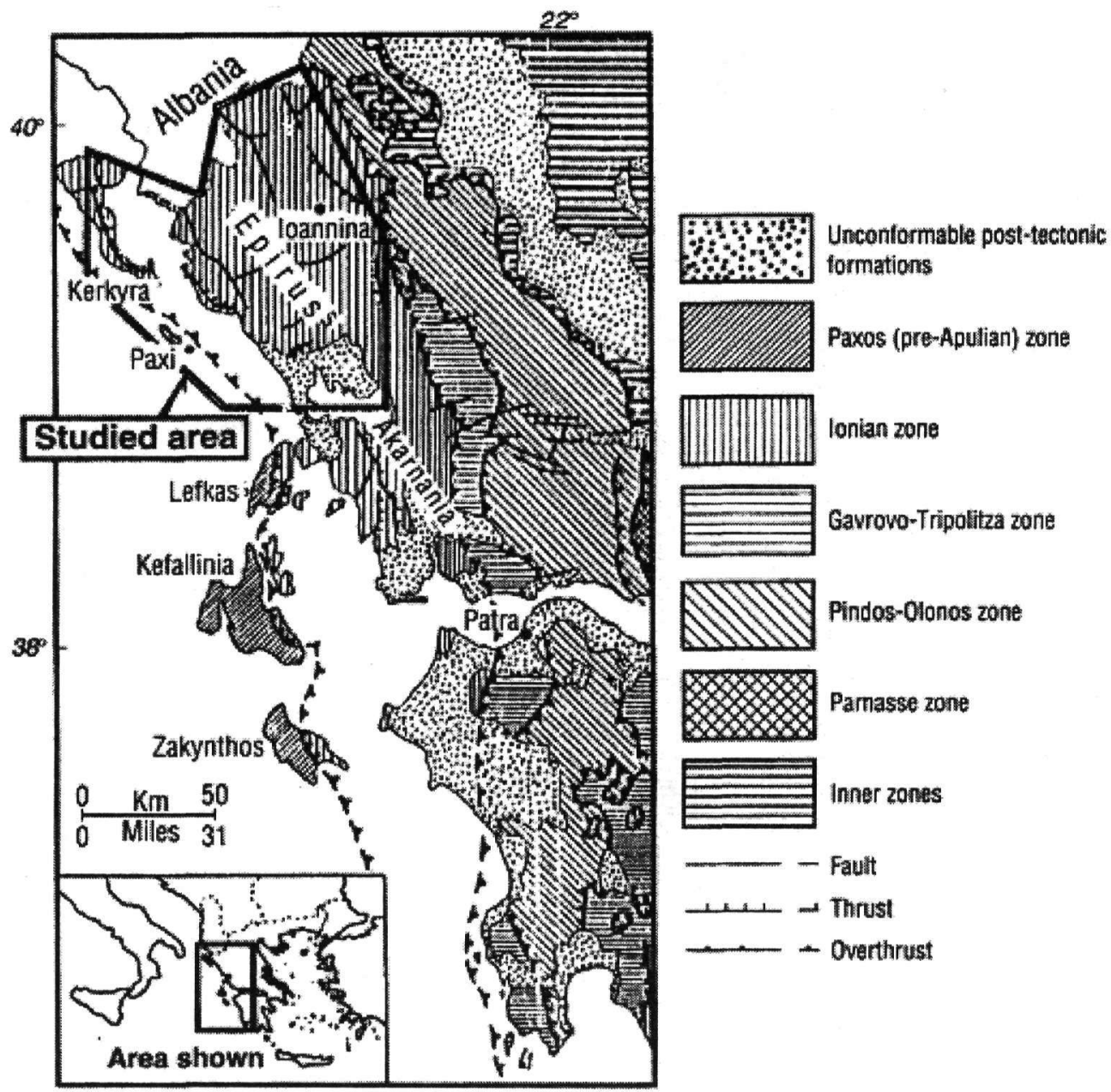

Figure 2. Simplified structural map of western continental Greece (Karakitsios, 1995) 


\section{GEOLOGICAL FRAMEWORK}

The stratigraphy of the Ionian zone (Fig. 2) exhibits three distinct sequences (Karakitsios, 1995; Fig. 3):

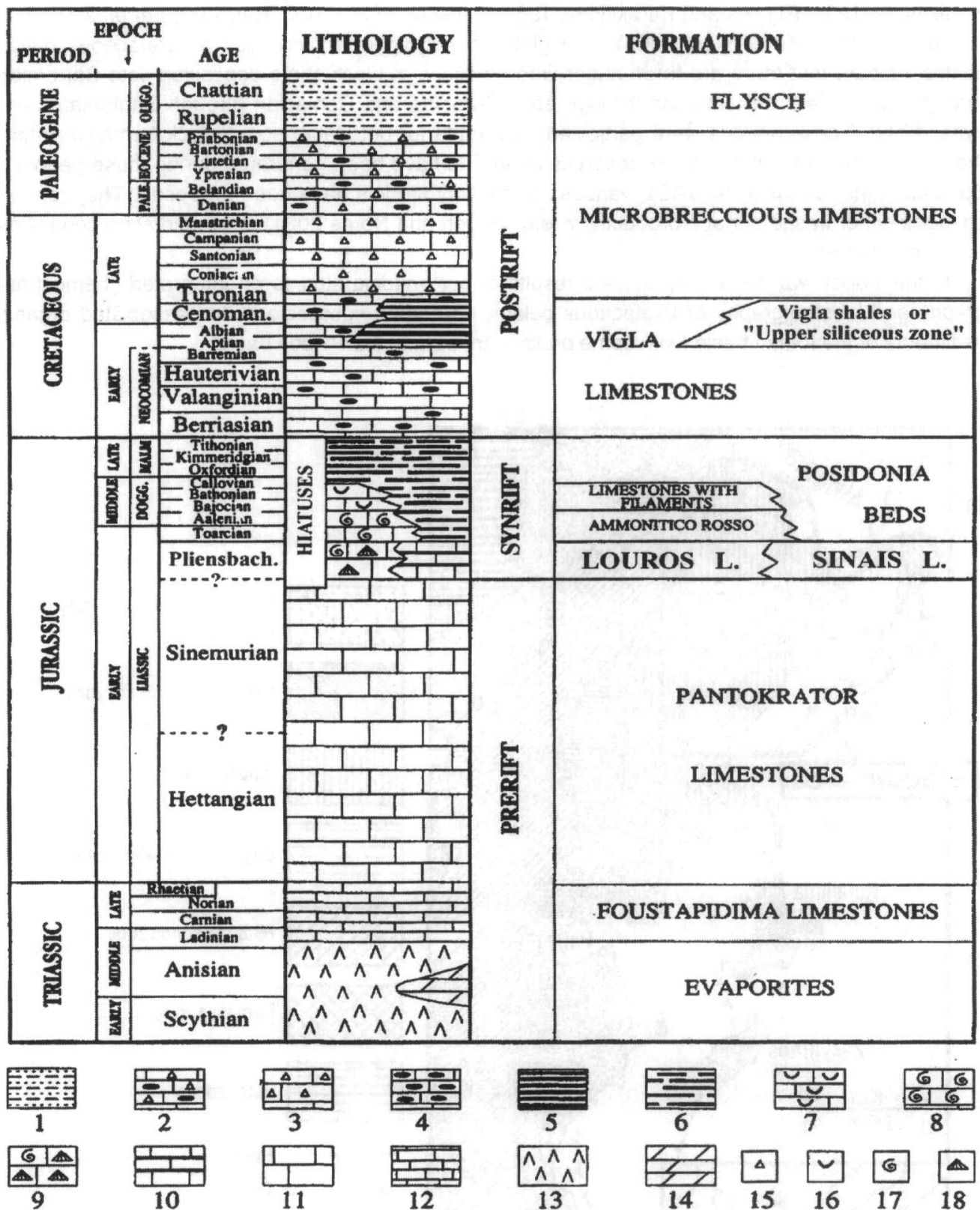

Figure 3. Representative stratigraphic column of the Ionian zone (Karakitsios, 1995). 1: pelites and sandstones; 2: cherty limestone with $\mathrm{cl}$ istic material; 3: pelagic limestones with clastic material; 5 : cherty beds with green and red clay, sometimes shaly; 6 : pelagic limestones, marls, and siliceous argillites; 7 : pelagic limestones with pelagic lamellibranches; 8: pelagic, red, nodular limestones with ammonites; 9: micritic limestones with small ammonites and brachiopods; 10: pelagic limestones; 11: platform limestones; 12: platy black limestones; 13 : gypsum and salt; 14: dolomites; 15: breccia; 16: section of pelagic lamellibranch (filament); 17: ammonite; 18 : brachiopod. 
a) A prerift sequence, which is represented by the early Liassic Pantokrator Limestones. These shallow water limestones overlie early to middle Triassic evaporites through Foustapidima Limestones of Ladinian-Rhaetian age.

b) A synrift sequence that began with the deposition of the Siniais Limestones and their lateral equivalent, the Louros Limestones of Pliensbachian age. These formations correspond to the general sinking of the Ionian domain (formation of the lonian basin), which was followed by an intrabasinal differentiation that separated the initial basin into smaller paleogeographic units presenting, in general, a half-graben geometry. This is recorded in the abruptly changing thickness of the synrift formations, forming prismatic synsedimentary wedges, which, in the deeper part of the halfgrabens, include complete Toarcian to Tithonian successions, while in the elevated part of the halfgrabens hiatuses and unconformities are located. Deposition was controlled both by structures formed during the extensional tectonic phase (related to the opening of the Neotethys Ocean), and the halokinesis of the Ionian zone evaporitic base.

c) A postrift sequence is defined by an Early Berriasian breakup that is marked by an unconformity at the base of the Vigla Limestones (over the elevated part of the synrift half grabens). The postrift sequence (Vigla Limestones and overlying Alpine formations) largely obscures the synrift structures and, in some cases, directly overlies the Pantokrator Limestones prerift sequence. The permanence of differential subsidence during the deposition of the Vigla Limestones as shown by the strong variation in the thickness of this formation, is probably due to the continuation of halokinetic phenomena of the Ionian zone evaporitic base. This paleogeographic configuration continued with minor off- and on-lap movements along basin margins until the late Eocene, when orogenic movements and flysch sedimentation began.

The main orogenic niovements took place at the end of the Burdigalian (IGRS-IFP, 1966). The Ionian basin evolution constitutes a good example of inversion tectonics of a basin with evaporitic base (Karakitsios, 1995).

\section{OBSERVATIONS}

In the Ionian zone, the Vigla limestone Formation (Berriasian-Turonian) comprises a thick succession of thin-layered $(5-10 \mathrm{~cm})$, sublithographic, pelagic limestones, with abundant radiolaria and frequent cherty beds with radiolaria. In the upper part, this formation contains a series of organic matter-rich marlstones and shales interbedded in limestone and chert beds: the Vigla shale Member. This member corresponds to the "Upper Siliceous Zone" of IGRS-IFP (1966). Since the attribution of the "Upper Siliceous Zone" to the Albian-Cenomanian by IGRS-IFP (1966) very few detailed biostratigraphic studies have been carried out (e.g. Skourtsis-Coroneou et al., 1995). We examined the Vigla limestone Formation in the suitable Gotzikas section, located in the homonymous valley, south of Tsamantas village in NW Epirus (Fig. 4).

In this section the Vigla shale Member comprises 27 (dm-thick) organic matter-rich calcareous mudstones and shales, within partially silicified limestone beds (Fig. 5). Samples were collected on a $\mathrm{cm}$ - to dm-scale in the lowermost part of the section where organic-rich intervals were more common, and on a meter-scale in the uppermost portion. All samples were analyzed for bulk carbonate $(\mathrm{C}, \mathrm{O})$ and total organic carbon (TOC) stable isotopes. A more detailed organic geochemical study on solvent-extractable organic matter was conducted on a smaller, selected sample suite. A detailed biostratigrphy, based on planktonic foraminifera and calcareous nannofossils, was also curried out. 


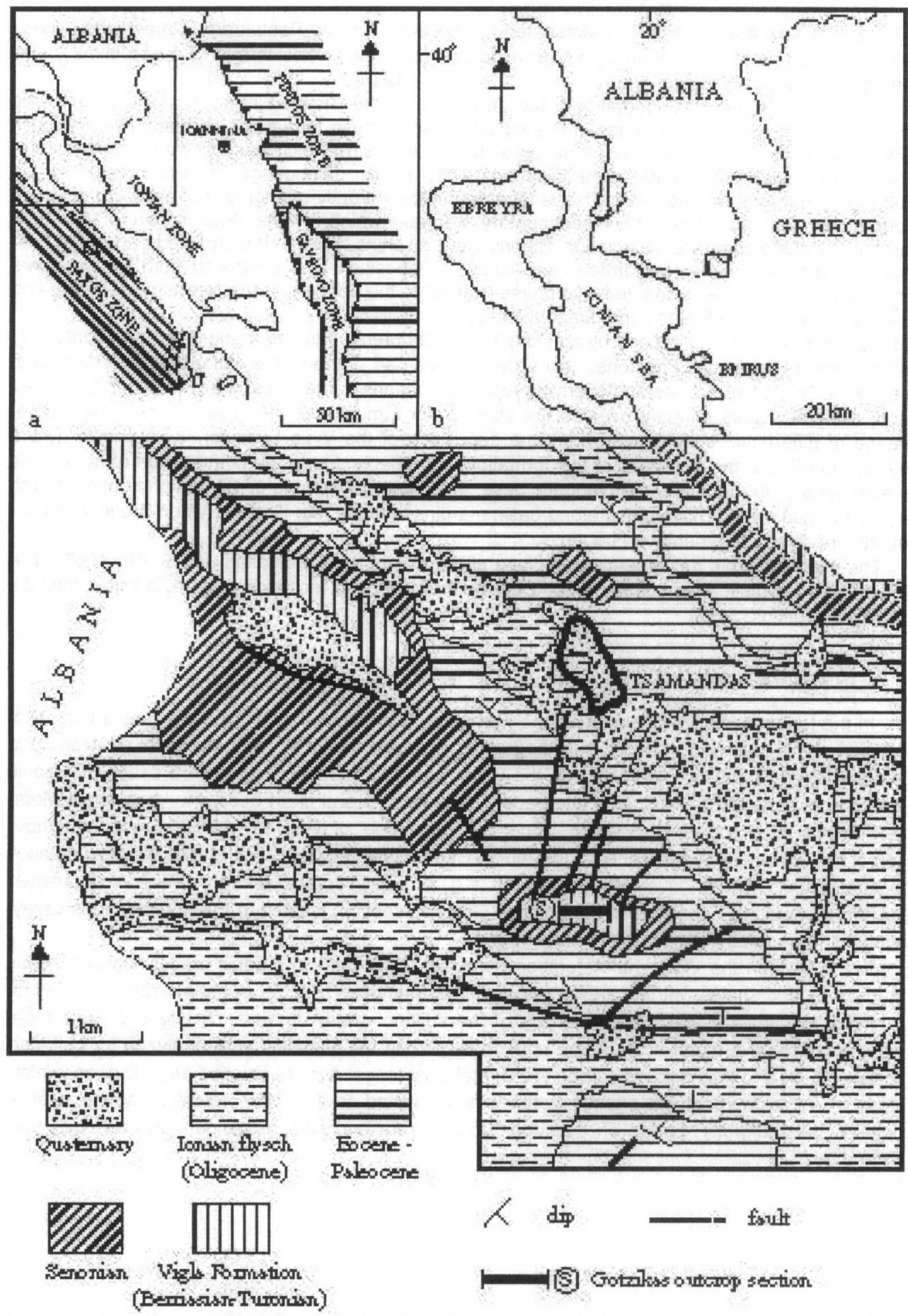

Figure 4. A: The Zones of NW Hellenids; B: Location of the study area; C: Simplified geological map of the study area (after IGRS-IFP 1966, modified): (S): geological section. 


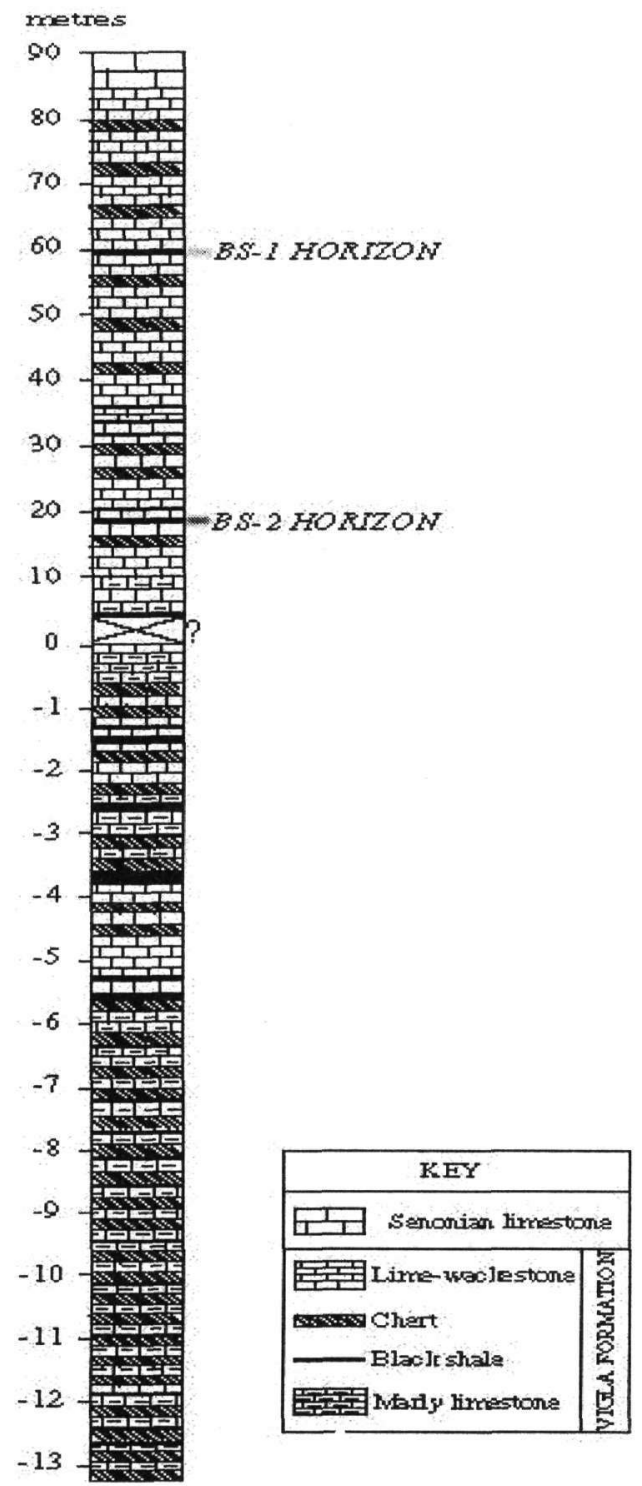

Figure 5. Lithostratigraphic log of the Gotzikas section. 27 organic carbon rich horizons are observed; two of them (BS1 and BS2) are true black-shale deposits. Note the different scales for the section above and below the section gap.

\subsection{Chemostratigraphy and bulk organic geochemistry}

Chemically, all but two of the TOC-rich horizons examined can be described as organic carbonbearing marls, with TOC contents ranging from 1 to 6 wt\%, bulk $\delta^{13} \mathrm{C}_{\text {TOC }}$ values (Fig. 6 ) between -

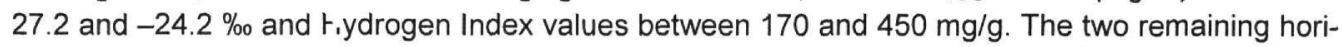
zons are located in the middle and upper part of the examined section and are hereafter referred to as BS1 and BS2 (for the stratigraphically upper and lower ones, respectively). Both BS1 and BS2 display clear characteristics of true black-shale deposits, with markedly higher TOC content $(44.5$ and 28.9 wt \% respectively) and much higher $\delta^{13} \mathrm{C}_{\text {TOC }}$ values $(-22.2$ and $-22.1 \%$ respectively), 
relative to those seen in the surrounding TOC-rich marls. The rise in $\delta^{13} \mathrm{C}_{\mathrm{TOC}}$ of the $\mathrm{BS} 2$ horizon coincides with a respective, positive shift in bulk carbonate $\delta^{13} \mathrm{C}$ values in limestone immediately below BS2 horizon. On the contrary, the BS1 horizon did not give any bulk carbonate $\delta^{13} \mathrm{C}$ value, due to its particularly high TOC content (44.5 wt\%).

The sharp positive shifts in $\delta^{13} \mathrm{C}_{\mathrm{TOC}}$ in both these horizons appear to be due to diverse causes. Biomarker evidence from the upper (BS1) horizon indicates a substantial relative contribution by bacteria, as indicated by the predominance of hopanoids in apolar hydrocarbon fractions. Moreover, the co-occurrence of lesser 2-methyl-hopanoids implies an additional, more specific cyanobacterial source. The above observations are in concert with other organic-rich marine sections of the world that straddle the Cenomanian-Turonian boundary interval, suggesting that the BS1 horizon may represent a new example for the well-documented Oceanic Anoxic Event (OAE) 2 (see Tsikos et al. in press, and references therein). The OAE 2 is typified by essentially coeval, worldwide deposition of organic carbon-rich sediments, accompanied by positive isotopic shifts in both marine carbon (organic and inorganic) and terrestrial organic matter.

On the contrary, the predominance of isotopically heavy cyclic isoprenoids relative to steroids/hopanoids in the lower, BS2 horizon, point to an episodic, sharp increase in the relative contribution of marine chemoautotrophic archaea to the organic matter, in addition to a primarily algal source. This is believed to account for the relatively high bulk $\delta^{13} \mathrm{C}_{\mathrm{TOC}}$ value of horizon $\mathrm{BS} 2$, making the latter a likely equivalent to the so-called Paquier event (or Oceanic Anoxic Event $1 \mathrm{~b}$ ) of the Lower Albian (Vink 1996; Vink et al. 1998; Kuypers et al. 2002). On the basis of currently available literature, the Paquier event is known to characterize only the Tethys-Atlantic regions (see Tsikos et al., 2003).

\subsection{Biostratigraphy}

Planktonic foraminifera and nannofossil biostratigraphy across the Gotzikas section provided the following results (Fig. 7):

-The BS1 horizon corresponds to the Cenomanian/Turonian boundary interval. This is indicated by the presence of the planktonic foraminiferal association: Rotalipora appenninica, $R$. cushmani (Middle Cenomanian) in the first 6 meters of the limestone immediately underlying the BS1 horizon, and of Praeglolotruncana gibba (Late Cenomanian - Middle Turonian) in the first 5 meters of the limestone immediately overlying the BS1 horizon.

-Stratigraphically higher, the occurrence of Marginotruncana gr. pseudolinneiana places a minimum upper age constraint for the examined section in Gotzikas, at the Upper Turonian (Caron, 1985).

-The BS2 horizon is attributed to the Lower-Middle Albian age-span. This is specifically suggested by the presence of calcareous nannofossil Hayesites albiensis (Early - Middle Albian) in the limestone interval $3 \mathrm{~m}$ stratigraphically below and $10 \mathrm{~m}$ above the BS2 horizon, respectively. This is reinforced by the first occurrences of the calcareous nannofossil Eiffellithus turriseiffelii (Upper Albian - Maastrichtian), and the planktonic foraminifera Biticinella breggiensis (Middle - Upper Albian), Planomalina buxtorfi (Upper Albian), Rotalipora appeninica (Upper Albian), after the 7-10 first meters above the BS2 horizon.

-The occurrence of the Early Aptian calcareous nannofossils (Assipetra infracretacea larsonii, Rucinolithus terebrodentarius youngii) in the base of Vigla shale Member places the lower stratigraphic level of this member to the Early Aptian. 


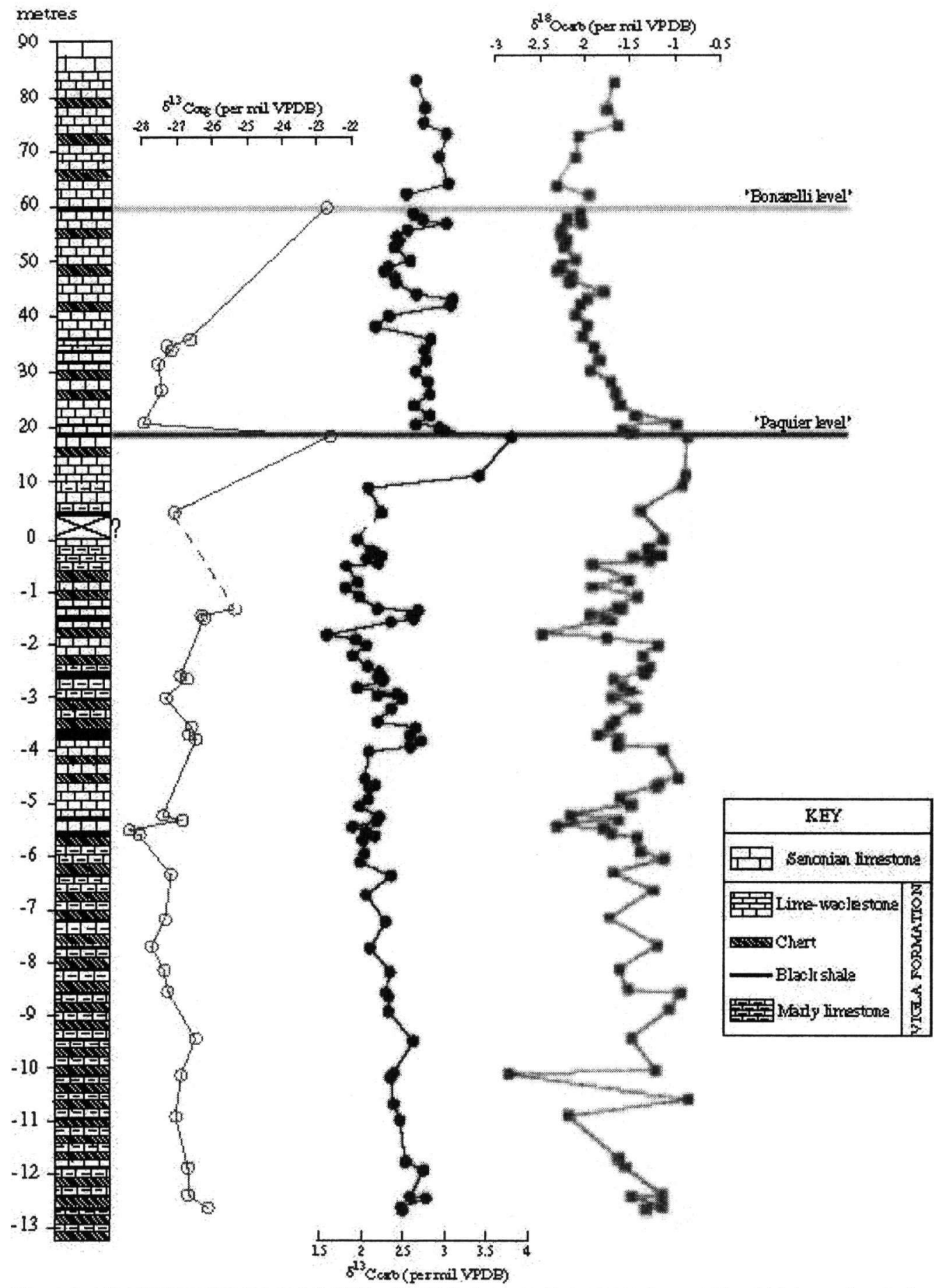

Figure 6. Lithostratigraphic log and $\delta$ stable $(C, O)$ isotope profiles across the examined Vigla section in the Gotzikas locality, Ionian zone, NW Greece. Note the different scales for the section above and below the section gap. 


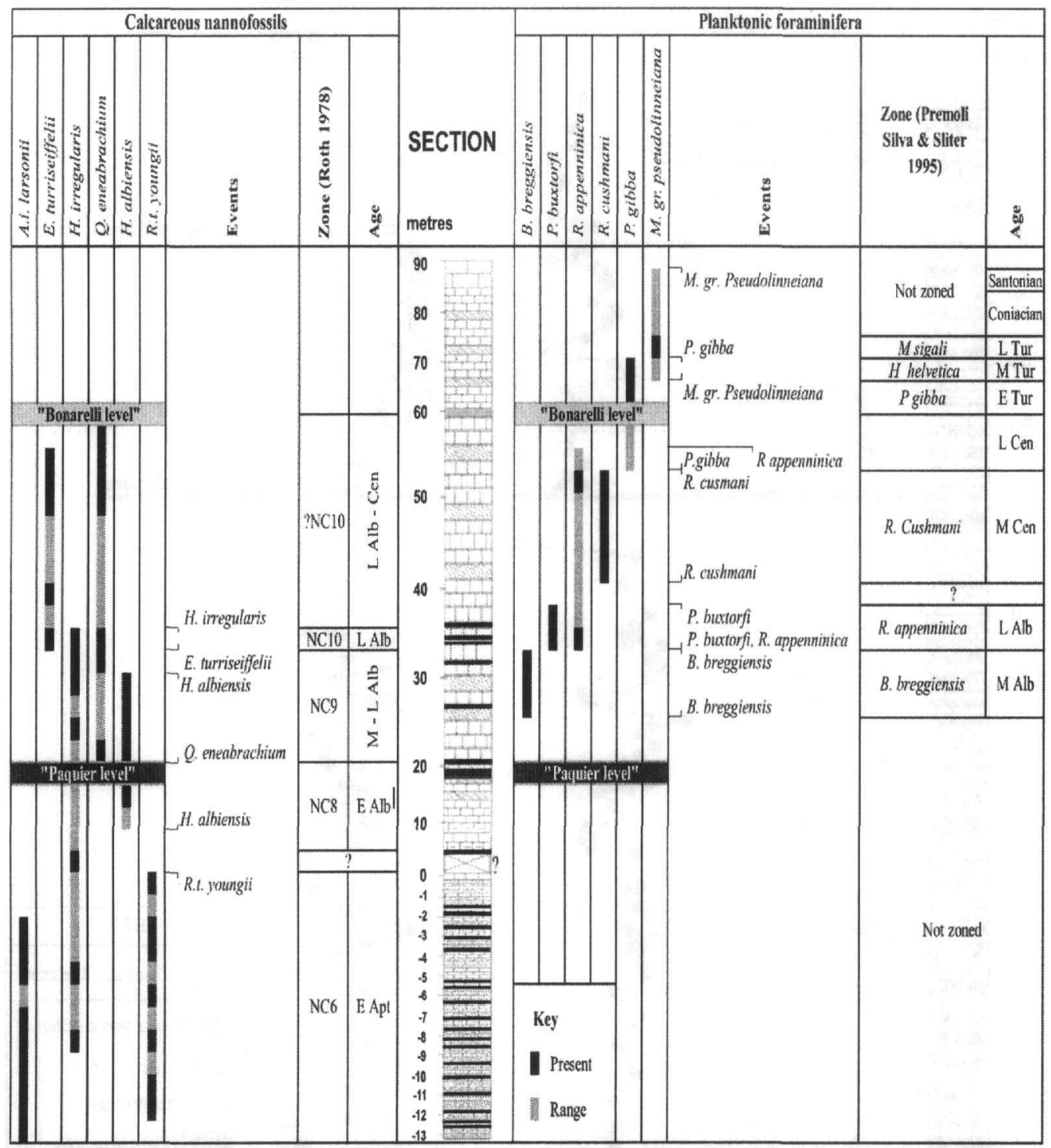

Figure 7. Summary of biostratigraphic information for the Gotzikas section. Biostatigraphy is based on observed distributions of calcareous nannofossils and planktonic foraminifera.

\subsection{Some preliminary data of the Pindos basin}

In the Kalarites section of the Pindos zone, SE Epirus (western Greece), we have identified, in the Aptian-Albian sediments of the series, a black shale horizon with TOC content $(21.7 \mathrm{wt} \%)$ and ${ }^{8}{ }^{13}{ }^{\text {T }}$ TOC value $(-24.1 \%$ ). These values are comparable with those of horizon BS2 (Paquier event) from the lonian basin. We are currently investigating further the possibility of a more concrete correlation between these two units, using detailed biostratigraphy and biomarker data.

\section{CONCLUSIONS}

The biostratigraphic data, combined with the chemostratigraphic and bulk organic geochemical evidence, show clearly that the BS1 and BS2 horizons of the lonian basin represent the 
lithological expressions of the Cenomanian-Turonian OAE (Bonarelli level), and of the Lower Albian OAE (Paquier event), respectively. Therefore, to our knowledge, the present study constitutes the first documentation in the literature of the Cenomanian-Turonian (OAE)2 and Lower Albian (OAE)1b Oceanic Anoxic Events from western Greece.

The biostratigraphic data show that the age of the Vigla shale Member, considered before as Albian-Cenomanian, is Aptian-Turonian in the Gotzikas area. Consequently, in the entire lonian ba$\sin$, the age of the Vigla shale member is either Aptian-Turonian or its deposition is diachronous.

The black shale horizon of Pindos zone (Kalarites section) could potentially be equivalent to the BS2 horizon (Paquier event). Ongoing studies focus on a more concrete correlation between these two units

\section{REFERENCES}

Caron M., 1985. Cretaceols planktic foraminifera, in Plankton stratigraphy (Eds H.M. Bolli, J.B. Saunders and K. Perch-Nielsen), Cambridge University Press, 17-86.

Danelian T., Baudin F.,Gardin S. and Beltran C., 2002. Stratigraphie intégrée et paléocéanographie dans la partie moyenne du Crétacé de la zone ionienne en Grèce. Abstract, Docum. Lab. Géol. Lyon 156, 91-92.

Dercourt J., Ricou L.E. and Vriellynck B. (eds), 1993. Atlas Tethys Palaeoenvironmental Maps. Gauthier-Villars, Paris, 307 p., 14 maps, 1 pl.

Erbacher J., Huber B.T., Norris R.D and Markey M., 2001. Increased thermohaline stratification as a possible cause for an oceanic anoxic event in the Cretaceous period. Nature 409, 325-327.

Jenkyns H.C., 1988. The Early Toarcian (Jurassic) Anoxic Event: Stratigraphic, Sedimentary, and Geochemical Evidence. Am. J. Sci. 288, 101-151.

Jenkyns H.C., 1999. Mesożoic anoxic events and palaeoclimate, Zentrallbatt Geol. Palaontol., 1997, 943-949.

Karakitsios V., 1995. The Influence of Preexisting Structure and Halokinesis on Organic Metter Preservation and Thrust System Evolution in the Ionian Basin, Northwestern Greece. AAPG Bulletin 79, 960-980.

Karakitsios V., 2003. Evolution and Petroleum Potential of the Ionian Basin (Northwest Greece). International Conference \& Exhibition 2003, AAPG, p 47.

Karakitsios V., Tsikos H., Walsworth-Bell B. \& Petrizzo M.R., 2002. Preliminary Results on Cretaceous Oceanic Anoxic Events (OAEs) of the Ionian Zone (W. Greece). Abstract, Docum. Lab. Géol. Lyon 156, 137-138.

Kuypers M.M.M., Blokker P., Hopmans E.C., Kinkel H., Pancost R.D., Schouten S., and Sinninghe Damste J.S., 2002. Archaeal remains domonate marine organic matter from the early Albien oceanic anoxic event $1 \mathrm{~b}$. Paaegeography, Palaenclimatology, Palaeoecology 185, 211-234.

Perch-Nielsen K., 1985a. Mesozoic calcareous nannofossils, in Plankton stratigraphy (Eds. H.M. Bolli, J.B. Saunders and K. Perch-Nielsen), Cambridge University Press, 329-426.

Premoli Silva I. and Sliter W.V., 1994. Cretaceous planktonic foraminiferal biostratigraphy and evolutionary trends from the Bottaccione section, Gubbio, Italy. Palaeontographica Italica, 82, 1-89.

Rigakis N. and Karakitsios V., 1988. The source rock Horizons of the Ionian Basin (NW Greece). Marine and Petroleum Geology 15, 593-617.

Roth P.H., 1978. Cretaceous nannoplankton biostratigraphy and oceanography of the northwestern Atlantic Ocean. Init. Rep. Deep Sea Drilling Proj. 44, 731-760.

Skourtsis-Coroneou V., Solakious N. and Constantinidis I., 1995. Cretaceous stratigraphy of the Ionian Zone, Hellenides, western Graece. Cretaceous Res. 16, 539-558.

Tsikos H., Karakitsios V., Bombardiere L., Van Breugel Y., Sinninghe-Damsté J., Schouten s., Farrimond P., Tyson R.V., and Jenkyns H.C. 2003. The Oceanic Anoxic Event (OAE) 1B in the Ionian Basin, NW Greece: Organic Geochemical Evidence. Abstract, Mesozoic paleoceanography, SGF, 49-50.

Tsikos, H., Jenkyns, H.C., Walsworth-Bell, B., Petrizzo, M.R., Forster, A., Kolonic, S., Erba, E., Premoli Silva, I., Baas, M., Wagner, T. \& Sinninghe Damsté, J.S. (in press). Carbon-isotope stratigraphy recorded by the Cenomanian/Turonian Oceanic Anoxic Event (OAE2): correlation and implications based on three keylocalities. Journal of the Geological Society.

Vink A., 1996. Organic geochemical characterization of the Lower Albian Niveau Paquier; a key black shale horizon from Vocontian Basin (SE France). Unpublished report, Department of Marine Biogeochemistry and Toxicology, Royal Netherlands Institute for Sea Research (NIOZ), 49p.

Vink A., Schouten S., Sephton S. and Sinninghe Damste J.S., 1998. A newly discovered norisoprenoid, 2,6,15,19-tetramethylicosane, in Cretaceous black shales. GEOCHIMICA ET Cosmochimica Acta 62, 965970.

Wilson P.A. and Norris R.D., 2001. Warm tropical ocean surface and global anoxia during Mid-Cretaceous period. Nature 412, 425-428. 